\title{
DETERMINAN FAKTOR INTERNAL DANA PIHAK KETIGA DAN FAKTOR EKSTERNAL (INFLASI, PENDAPATAN PERKAPITA, DAN IMBALAN SWBI) TERHADAP JUMLAH DANA TALANGAN HAJI PADA BANK SYARIAH (BNI SYARIAH, BRI SYARIAH, BANK MUAMALAT, BANK SYARIAH MANDIRI) PERIODE 2009-20141)
}

\author{
Fachmi Setyawan \\ Mahasiswa Program Studi Ekonomi Islam-Fakultas Ekonomi dan Bisnis-Universitas Airlangga \\ Email: fachmisetyawan-12@feb.unair.ac.id \\ Suherman Rosyidi \\ Departemen Ekonomi Syariah-Fakultas Ekonomi dan Bisnis-Universitas Airlangga \\ Email:srosyidi@gmail.com
}

\begin{abstract}
:
This study aimed to analyze the influence of internal factors of Islamic banks are third party funds and macroeconomic factors, namely inflation, percapita income and rewards Wadiah Certificate of Bank Indonesia to the amount of their bailout Hajj by Sharia banks in Indonesia during the period January 2009 to December 2014. The approach using multiple linear regression analysis. In this study, most of the hypothesis is not proven. Only variables percapita income and rewards SWBI that meet the research hypothesis. Research shows that third party funds and variable inflation rate indication hit double colinearity problems, so as to avoid bias regression results of these two variables were excluded from the regression model. Percapita income and rewards SWBIs have a significant effect partially to the amount of their bailout Hajj. Effect relationship shown is the reward SWBI have a negative effect, while percapita income has a positive influence on the amount of their bailout Hajj.
\end{abstract}

Keywords:Bailout Hajj, Third Party Funds, Inflation, Rewards SWBI, and Percapita Income.

\section{Pendahuluan}

Lembaga bank merupakan salah satu institusi yang sangat penting dan sangat berpengaruh dalam dinamika ekonomi modern saat ini. Bank mempunyai peran yang sangat besar dalam memajukan suatu negara karena hampir semua sektor yang berhubungan dengan berbagai kegiatan kevangan selalu membutuhkan jasa perbankan. Tidak ada satu pun negara yang mampu menjalankan perekonomian dengan baik tanpa melibatkan lembaga keuangan seperti bank, karena bank dapat mempermudah segala bentuk transaksi kevangan baik transaksi kevangan dalam negeri maupun transaksi keuangan antar negara.
Dewasa ini tidak hanya bank konvensional saja yang menjadi pilihan bagi masyarakat Indonesia, akan tetapi juga bank syariah. Didirikannya bank syariah dilatarbeakangi oleh keinginan umat Islam untuk menghindari riba dalam kegiatan muamalah mereka. Lebih lanjut pengaruh kemajuan teknologi dan informasi memberi dampak positif bagi bank syariah yaitu semakin berkembangnya berbagai produk inovatif dari bank syariah sesuai dengan kebutuhan masyarakat yang ada. Salah satu kebutuhan masyarakat Indonesia saat ini yang paling banyak diinginkan adalah menunaikan ibadah haji.

Di antara lima rukun Islam, menunaikan ibadah haji merupakan

1) Jurnal ini merupakan bagian dari skripsi yang ditulis oleh Fachmi Setyawan, NIM: 041211432027 yang diuji pada 13 Juni 2016. 
Setyawan, et al/Jurnal Ekonomi Syariah Teori dan Terapan Vol. 4 No. 3 Maret 2017: 235-252; DETERMINAN FAKTOR INTERNAL DANA PIHAK KETIGA DAN FAKTOR EKSTERNAL (INFLASI, PENDAPATAN PERKAPITA, DAN IMBALAN SWBI) TERHADAP JUMLAH DANA TALANGAN HAJI PADA BANK SYARIAH(BNI SYARIAH, BRI SYARIAH, BANK MUAMALAT, BANK SYARIAH MANDIRI)

PERIODE 2009-2014

ibadah yang sangat istimewa bagi umat Islam sebab Allah SWT telah menjanjikan pahala yang besar bagi siapa saja yang menunaikan ibadah haji dengan sungguh-sungguh. Hal ini sesuai dengan Firman Allah SWT di dalam Al-Quran yaitu surat Ali Imran, ayat 96-97:

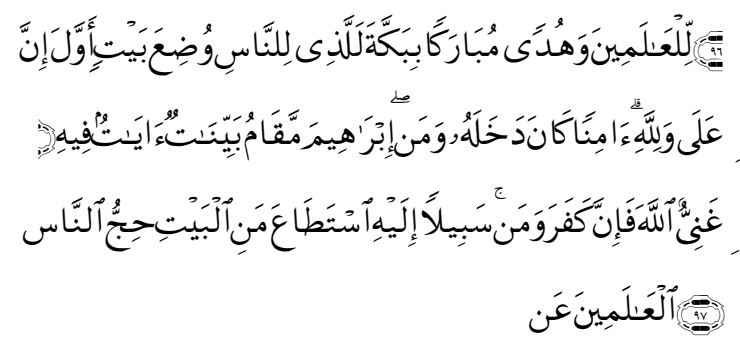

Yang artinya: "Sesungguhnya rumah yang mula-mula dibangun untuk (tempat beribadat) manusia, ialah Baitullah yang di Bakkah (Mekah) yang diberkahi dan menjadi petunjuk bagi semua manusia. Padanya terdapat tanda-tanda yang nyata, (di antaranya) maqam Ibrahim. Barangsiapa memasukinya (Baitullah itu) menjadi amanlah dia. Mengerjakan haji adalah kewajiban manusia terhadap Allah, yaitu (bagi) orang yang sanggup mengadakan perjalanan ke Baitullah. Barangsiapa mengingkari (kewajiban haji), maka sesungguhnya Allah Maha Kaya (tidak memerlukan sesuatu) dari semesta alam"(Q.S. Ali Imran: 96-97).

Banyak segi kehidupan bermasyarakat yang terlibat dalam penyelenggaraan ibadah haji, mulai dari persepsi masyarakat terhadap makna haji, nilai dan norma agama yang terkandung di dalamnya, hingga yang paling utama adalah status bagi orang yang telah berhaji. Konsekuensi logis dari semua itu berdampak pada tingginya minat masyarakat Indonesia untuk menunaikan ibadah haji yang setiap tahunnya terus mengalami peningkatan yang cukup signifikan, bahkan melampaui dari batas kuota yang telah ditetapkan oleh pemerintah Arab Saudi

Banyak sekali anggota masyarakat yang ingin menunaikan ibadah haji, namun terkendala oleh belum terkumpulnya dana tunai yang dimiliki guna mendaftarkan diri untuk mendapatkan kursi keberangkatan haji. Berangkat dari alasan itulah, bank syariah ingin memberi keringanan (takhfif) untuk membantu masyarakat muslim menunaikan ibadah haji degan mengeluarkan produk dana talangan haji. Landasan hukum syariah dari produk ini adalah Fatwa Dewan Syariah NasionalMajelis Ulama Indonesia (DSN-MUI) No. 29/DSN-MUI/VI/2002 yang secara lengkap berbunyi:

1. Dalam pengurusan haji, lembaga kevangan syariah dapat memperoleh imbalan jasa (ujrah) dengan menggunakan prinsip Alljarah sesuai Fatwa No.9/DSN$\mathrm{MUI} / \mathrm{IV} / 2000$.

2. Apabila diperlukan, lembaga kevangan syariah dapat membantu memberi talangan pembayaran biaya perjalanan ibadah haji (BPIH) nasabah dengan menggunakan prinsip AlQard sesuai Fatwa No.19/DSNMUI/IV/2001.

3. Jasa pengurusan haji yang dilakukan lembaga keuangan syariah tidak boleh dipersyaratkan dengan pemberian talangan haji.

4. Besar imbalan jasa Al-ljarah tidak boleh didasarkan pada jumlah talangan Al-Qard yang diberikan lembaga keuangan syariah kepada nasabah.

Sejatinya dana talangan haji adalah upaya memudahkan seseorang untuk menunaikan ibadah haji. Jika seseorang 
Setyawan, et al/Jurnal Ekonomi Syariah Teori dan Terapan Vol. 4 No. 3 Maret 2017: 235-252; DETERMINAN FAKTOR INTERNAL DANA PIHAK KETIGA DAN FAKTOR EKSTERNAL (INFLASI, PENDAPATAN PERKAPITA, DAN IMBALAN SWBI) TERHADAP JUMLAH DANA TALANGAN HAJI PADA BANK SYARIAH(BNI SYARIAH, BRI SYARIAH, BANK MUAMALAT, BANK SYARIAH MANDIRI)

PERIODE 2009-2014

secara finansial memiliki kepastian untuk membayar dana talangan dimasa yang akan datang, misalnya karena gaji yang cukup, atau penghasilan lain yang stabil maka dia dapat dikategorikan sebagai mampu berhaji.

Dalam perkembangannya, produk dana talangan haji mengalami peningkatan yang sangat signifikan. Namun, karena adanya pro-kontra di sebagian kalangan akademisi, serta adanya kebijakan dari Kementerian Agama yang memperketat produk dana talangan haji, menyebabkan sejak tahun 2013 produk dana talangan haji ini mengalami penurunan jika dibandingkan tahun-tahun sebelumnya.

Tabel 1.

Pertumbuhan Produk Dana Talangan Haji (dalam Jutaan Rupiah)

\begin{tabular}{|c|c|c|c|c|}
\hline & $\begin{array}{c}\text { BRI } \\
\text { Syariah }\end{array}$ & $\begin{array}{c}\text { Bank } \\
\text { Syariah } \\
\text { Mandiri } \\
\text { (BSM) }\end{array}$ & $\begin{array}{c}\text { Muamal } \\
\text { at }\end{array}$ & $\begin{array}{c}\text { BNI } \\
\text { Syariah }\end{array}$ \\
\hline 2009 & 1.670 & 797.600 & 202.400 & 25.000 \\
\hline 2010 & 79.980 & 1.630 .000 & 991.500 & 59.300 \\
\hline 2011 & 286.400 & 3.500 .000 & 1.200 .000 & 332.100 \\
\hline 2012 & 733.070 & 5.100 .000 & 653.200 & 820.800 \\
\hline 2013 & 567.170 & 4.300 .000 & 374.500 & 866.200 \\
\hline 2014 & 274.530 & 2.400 .000 & 116.500 & 721.400 \\
\hline
\end{tabular}

Sumber: Laporan keuangan (annual report) BRI Syariah, Bank Syariah Mandiri, Muamalat, dan BNI Syariah (data telah diolah).

Meskipun tergolong produk baru, pertumbuhan yang cepat dari produk dana talangan haji tentu akan memberikan manfaat dan keuntungan bagi kinerja bank syariah melalui fee based income yang diperoleh. Jumlah volume minat calon nasabah yang sangat tinggi menjadikan produk ini sangat menjanjikan bagi bank syariah
Penyaluran dana talangan haji pada bank syariah tidak terlepas dari dana pihak ketiga yang berhasil dihimpun oleh bank syariah tersebut. Hal ini dikarenakan, dana pihak ketiga adalah Dana-dana yang terhimpun dari masyarakat (DPK) merupakan sumber dana terbesar yang paling diandalkan oleh bank. Artinya bahwa, dana pihak ketiga mempunyai peran penting dalam peningkatan ataupun penurunan penyaluran dana yang dilakukan oleh bank syariah. Seiring dengan minat masyarakat yang sangat tinggi akan produk dana talangan haji maka perlu diimbangi pula oleh ketersediaan dana yang dapat disalurkan oleh bank syariah untuk produk dana talangan haji. Sehingga bank syariah harus meningkatkan sumber dana pihak ketiga agar ketersediaan dana yang dapat disalurkan semakin meningkat. Dengan meningkatnya dana pihak ketiga yang dikelola oleh bank syariah maka kebutuhan dana untuk disalurkan pada produk seperti dana talangan haji ini akan dapat terpenuhi.

Fluktuasi total jumlah dana talangan haji ini, selain disebabkan oleh faktor internal bank syariah seperti dana pihak ketiga yang terhimpun, juga tidak terlepas oleh faktor makroekonomi seperti tingkat inflasi, pendapatan perkapita nasional serta imbalan Sertifikat Wadiah Bank Indonesia (untuk seterusnya, akan disebut SWBI). 
Setyawan, et al/Jurnal Ekonomi Syariah Teori dan Terapan Vol. 4 No. 3 Maret 2017: 235-252; DETERMINAN FAKTOR INTERNAL DANA PIHAK KETIGA DAN FAKTOR EKSTERNAL (INFLASI, PENDAPATAN PERKAPITA, DAN IMBALAN SWBI) TERHADAP JUMLAH DANA TALANGAN HAJI PADA BANK SYARIAH(BNI SYARIAH, BRI SYARIAH, BANK MUAMALAT, BANK SYARIAH MANDIRI)

PERIODE 2009-2014

Terjadinya inflasi memberikan tekanan pada masyarakat yaitu dengan mengurangi nilai dari pendapatan masyarakat sehingga berdampak pada menurunnya daya beli masyarakat. Pada saat inflasi terjadi, masyarakat cenderung menyimpan vang mereka daripada membelanjakannya. Inflasi adalah suatu keadaan pada saat terjadi kenaikan harga-harga secara tajam yang berlangsung terus-menerus dalam jangka waktu yang lama. Inflasi merupakan salah satu indikator makroekonomi yang dapat mempengaruhi pembiayaan pada bank syariah.

Selain tingkat inflasi, faktor pendapatan perkapita juga mempunyai andil dalam mempengaruhi minat masyarakat dalam melaksanakan ibadah haji. Pendapatan perkapita merupakan tolok ukur kemampuan ekonomi masyarakat yang digunakan untuk melihat tingkat kesejahteraan dari masyarakat tersebut. Jika pendapatan perkapita masyarakat semakin tinggi maka kemampuan ekonomi masyarakat juga akan semakin baik. Kemampuan ekonomi yang semakin baik artinya bahwa tingkat kesejahteraan masyaraakat juga akan semakin baik.

Dari sisi bank syariah, pilihan untuk menempatkan dana yang dikelola oleh bank syariah menjadi hal yang sangat penting. Bank syariah mempunyai pilihan apakah menempatkan dananya pada Bank Indonesia atau disalurkan kembali pada masyarakat dalam bentuk pembiayaan, investasi maupun dana pinjaman. Tentu dalam mengelola dananya, bank syariah akan lebih memilih menempatkan dananya pada kegiatan yang memberikan keuntungan paling besar. Salah satu bentuk penempatan dana jangka pendek pada Bank Indonesia adalah SWBI. Imbalan yang diberikan oleh Bank Indonesia kepada pemegang sertifikat ini adalah berupa bonus yang diberikan pada saat jatuh tempo. Jika imbalan yang diberikan semakin rendah, maka bank syariah akan leboh memilih untuk menyalurkan dananya pada masyarakat dibanding ditempatkan pada SWBI.

Berdasarkan uraian di atas, rumusan masalah yang ingin diajukan dalam penelitian ini adalah apakah jumlah dana pihak ketiga, tingkat inflasi, pendapatan perkapita dan imbalan SWBI berpengaruh signifikan secara simultan maupun secara parsial terhadap jumlah besaran dana talangan haji pada bank syariah.

\section{LANDASAN TEORI}

Sebagai salah satu rukun Islam, ibadah haji diwajibkan bagi setiap muslim yang mampu secara fisik dan ekonomi tatkala diturunkannya wahyu dari Allah SWT yang terdapat dalam Al-Quran surat Al Hajj ayat 27:

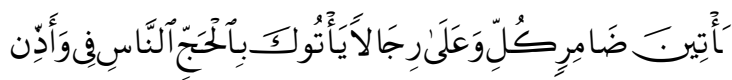

$$
\begin{aligned}
& \text { عَمَمِقِفَجْ كُلِّمِنِ }
\end{aligned}
$$

Yang artinya "Dan berserulah kepada manusia untuk mengerjakan haji, niscaya mereka akan datang kepadamu dengan berjalan kaki, dan mengendarai unta 
Setyawan, et al/Jurnal Ekonomi Syariah Teori dan Terapan Vol. 4 No. 3 Maret 2017: 235-252; DETERMINAN FAKTOR INTERNAL DANA PIHAK KETIGA DAN FAKTOR EKSTERNAL (INFLASI, PENDAPATAN PERKAPITA, DAN IMBALAN SWBI) TERHADAP JUMLAH DANA TALANGAN HAJI PADA BANK SYARIAH(BNI SYARIAH, BRI SYARIAH, BANK MUAMALAT, BANK SYARIAH MANDIRI)

PERIODE 2009-2014

yang kurus yang datang dari segenap penjuru yang jauh"(Q.S. Al Hajj:27).

Produk dana talangan haji

mempunyai dasar fikih halal melalui Fatwa yang telah dikeluarkan oleh Dewan Syariah Nasional - Majelis Ulama Indonesia No. 29/DSN-MUI/VI/2002 tentang dana talangan dan pengurusan haji yang dilakukan oleh Lembaga Keuangan Syariah. Di dalam Fatwa DSN-MUI tersebut dikatakan bahwa akad yang digunakan dalam produk dana talangan haji adalah akad qard wal ijarah. Sesuai Fatwa DSNMUI, dari akad dana talangan haji terdapat dua obyek yang berbeda, yakni vang dan jasa. Pertama, akad qard (pinjaman) mempunyai obyek berupa vang yang dipinjamkan oleh bank syariah hanya untuk keperluan menutupi kekurangan biaya pendaftran haji nasabah. Pada akad ini, nasabah hanya wajib mengembalikan dana talangan sebesar pokok yang mereka pinjam dari bank syariah. Kedua, akad ijarah digunakan untuk jasa pengurusan ibadah haji. Dalam prakteknya, bank syariah yang membantu nasabah untuk memperoleh porsi keberangkatan haji mempunyai hak untuk mendapatkan ujrah atas pekerjaan berupa pelayanan pengurusan haji tersebut. Sehingga dari penjelasan tersebut, akad pada produk dana talangan haji dilakukan secara terpisah dan menjadi dasar dibolehkannya produk dana talangan haji oleh Majelis Ulama Indonesia.
Pada dasarnya, dana talangan haji adalah fasilitas kemudahan yang diberikan oleh bank syariah kepada seseorang yang ingin sekali untuk menunaikan ibadah haji. Dalam prakteknya, seseorang yang ingin menggunakan produk dana talangan haji harusah sesuai kriteria yang telah ditetapkan oleh bank syariah. Bank syariah tentu memiliki aspek-aspek kriteria seperti pendapatan, jumlah tanggungan keluarga dan lain-lain. Artinya bahwa seseorang yang tidak memiliki pendapatan yang stabil atau mencukupi maka tidak diperbolehkan untuk menggunakan produk dana talangan haji ini.

Dari penjelasan di atas dapat diambil kesimpulan bahwa dana talangan haji bertujuan untuk memberikan keringanan (takhfif) kepada seseorang yang memang sangat ingin sekali menunaikan ibadah haji. Keringanan yang dimaksud adalah dalam mendapatkan kursi keberangkatan haji. Pemberian dana talangan hanya ditujukan bagi orang yang memiliki kemampuan membayar dana talangan sebelum pelaksanaan keberangkatan haji. Artinya dana talangan hanya diberikan bagi orang yang mampu melunasi, bukan orang yang sama sekali tidak mampu secara finansial sehingga keberangkatan haji tidak dalam kondisi berhutang.

Terdapat dua faktor yang dapat mempengaruhi suatu pembiayaan pada 
Setyawan, et al/Jurnal Ekonomi Syariah Teori dan Terapan Vol. 4 No. 3 Maret 2017: 235-252; DETERMINAN FAKTOR INTERNAL DANA PIHAK KETIGA DAN FAKTOR EKSTERNAL (INFLASI, PENDAPATAN PERKAPITA, DAN IMBALAN SWBI) TERHADAP JUMLAH DANA TALANGAN HAJI PADA BANK SYARIAH(BNI SYARIAH, BRI SYARIAH, BANK MUAMALAT, BANK SYARIAH MANDIRI)

PERIODE 2009-2014

lembaga bank yaitu faktor internal dan faktor eksternal. Pada penelitian ini, faktorfaktor yang digunakan sebagai variabel bebas yaitu faktor internal yang menggunakan variabel dana pihak ketiga yang terhimpun serta faktor eksternal yang meliputi tingkat inflasi, pendapatan perkapita nasional dan imbalan Sertifikat Wadiah Bank Indonesia.

Salah satu faktor penting yang mempengaruhi kemampuan penyaluran pembiayaan yang dilakukan oleh bank syariah adalah jumlah dana pihak ketiga yang dapat dihimpun oleh bank syariah tersebut. Tingkat penyaluran dana untuk pembiayaan di bank syariah, dipengaruhi oleh seberapa besar jumlah dana yang dikelola oleh bank syariah tersebut. jumlah dana pihak ketiga yang terhimpun dengan pembiayaan dana talangan haji mempunyai hubungan yang positif. Artinya semakin besar dana pihak ketiga yang terhimpun maka semakin besar pula dana yang bisa disalurkan untuk dana talangan haji, sehingga berimplikasi pada semakin tingginya jumlah besaran dana talangan haji. Semakin rendah dana pihak ketiga yang terhimpun di bank syariah, maka semakin rendah pula jumlah dana yang dapat disalurkan untuk dana talangan haji. Dan pada akhirnya berimplikasi pada turunnya jumlah besaran dana talangan haji di bank syariah.

Inflasi dan dana talangan haji mempunyai hubungan yang negatif. Pada saat tingkat harga kebutuhan bahan pokok tinggi (inflasi naik) maka akan mempengaruhi minat masyarakat untuk melaksanakan ibadah haji. Masyarakat akan lebih memilih untuk memenuhi kebutuhan pokok mereka terlebih dahulu dibanding melakukan perjalanan ibadah haji. Dari penjelasan di atas, dapat disimpulkan bahwa jika inflasi tinggi maka minat masyarakat untuk melaksanakan ibadah haji akan semakin turun dan kemudian akan berimplikasi pada menurunnya jumlah besaran dana talangan haji. Akan tetapi, jika inflasi rendah maka minat masyarakat untuk melaksanakan ibadah haji akan semakin meningkat dan kemudian akan berimplikasi pada naiknya jumlah besaran dana talangan haji pada bank syariah.

Tingkat pendapatan perkapita masyarakat mempunyai hubungan yang positif dengan jumlah dana talangan haji. Artinya jika pendapatan perkapita masyarakat tinggi, maka minat masyarakat melaksanakan ibadah haji juga akan semakin tinggi. Minat masyarakat yang semakin tinggi untuk melaksanakan ibadah haji akan menyebabkan produk seperti dana talangan haji akan semakin diminati oleh masyarakat dan pada akhirnya akan meningkatkan jumlah dana talangan haji di bank syariah. Sebaliknya, jika tingkat pendapatan perkapita masyarakat semakin rendah maka minat masyarakat untuk melaksanakan ibadah haji juga semakin rendah. Semakin rendah minat masyarakat untuk melaksanakan ibadah 
Setyawan, et al/Jurnal Ekonomi Syariah Teori dan Terapan Vol. 4 No. 3 Maret 2017: 235-252; DETERMINAN FAKTOR INTERNAL DANA PIHAK KETIGA DAN FAKTOR EKSTERNAL (INFLASI, PENDAPATAN PERKAPITA, DAN IMBALAN SWBI) TERHADAP JUMLAH DANA TALANGAN HAJI PADA BANK SYARIAH(BNI SYARIAH, BRI SYARIAH, BANK MUAMALAT, BANK SYARIAH MANDIRI)

PERIODE 2009-2014

haji akan berimplikasi pada semakin rendahnya jumlah pembiayaan dana talangan haji di bank syariah.

Penerbitan instrument moneter SWBI oleh Bank Indonesia akan dapat mempengaruhi jumlah besaran dana talangan haji. Pengaruh tersebut ditunjukkan oleh hubungan yang negatif. Jika imbalan yang diberikan semakin tinggi, maka bank syariah akan lebih memilih menempatkan dananya pada instrument SWBI daripada menyalurkan dananya untuk dana talangan haji. Sebaliknya, jika imbalan yang diberikan semakin rendah maka bank syariah akan lebih memilih menyalurkan dananya untuk dana talangan haji. Bank syariah tentu akan memilih menempatkan dananya pada investasi yang memberikan keuntungan yang lebih besar. Sehingga dapat disimpulkan bahwa jika imbalanSWBI semakin tinggi maka dana talangan haji pada bank syariah akan semakin rendah. Namun jika imbalan SWBI semakin rendah maka dana talangan haji pada bank syariah akan semakin meningkat.

\section{METODE PENELITIAN}

\section{Pendekatan Penelitian}

Pendekatan penelitian yang digunakan dalam penelitian ini adalah pendekatan penelitian kuantitatif. Anshori dan Iswati (2009:13), mendefinisikan bahwa Penelitian kuantitatif adalah suatu metode penelitian yang mengkuantitatifkan data dan menerapkan satu bentuk analisis untuk menerima atau menolak hipotesis. Penelitian ini akan membuktikan pengaruh factor jumlah dana pihak ketiga dan faktor makroekonomi yaitu tingkat inflasi, pendapatan perkapita nasional dan imbalan SWBI terhadap jumlah besaran dana talangan haji. Untuk membuktikan pengaruh tersebut, dilakukan pengujian dengan menggunakan metode analisis berupa analisis regresi linier berganda (liniar multiple regression). Alasan penggunaan metode analisis regresi linier berganda adalah karena variabel bebas (independen) dalam penelitian ini lebih dari satu.

\section{Identifikasi Variabel}

Berdasarkan model analisis dan hipotesis, maka dapat diidentifikasi bahwa jumlah dana pihak ketiga, tingkat inflasi, pendapatan perkapita dan imbalan SWBI adalah sebagai variabel independen / bebassedangkan jumlah dana pihak ketiga merupakan variabel dependen/ terikat.

\section{Jenis dan Sumber Data}

Penelitian ini menggunakan data sekunder yang berupa data laporan keuangan pada empat bank syariah yang diambil dari hasil publikasi laoran keuangan dari bank syariah dan juga Bank Indonesia.Data sekunder yang digunakan dalam penelitian ini termasuk data time series yang diterbitkan pada tahun 2009 hingga tahun 2014 dengan skala nominal dan persentase.

\section{Sampel}


Setyawan, et al/Jurnal Ekonomi Syariah Teori dan Terapan Vol. 4 No. 3 Maret 2017: 235-252; DETERMINAN FAKTOR INTERNAL DANA PIHAK KETIGA DAN FAKTOR EKSTERNAL (INFLASI, PENDAPATAN PERKAPITA, DAN IMBALAN SWBI) TERHADAP JUMLAH DANA TALANGAN HAJI PADA BANK SYARIAH(BNI SYARIAH, BRI SYARIAH, BANK MUAMALAT, BANK SYARIAH MANDIRI) PERIODE 2009-2014

Di dalam penelitian ini tekhnik penentuan sampel yang digunakan adalah purposive sampling. Sampel yang digunakan pada penelitian ini adalah empat bank syariah terbesar di Indonesia yaitu Bank Muamalat, BNI Syariah, BRI Syariah, dan Bank Syariah Mandiri. Pemilihan sampel dilakukan dengan pertimbangan bahwa dari keempat bank syariah tersebut memiliki kontribusi jumlah dana talangan haji terbesar secara nasional

\section{Prosedur Pengumpulan Data}

Prosedur pengumpulan data melalui studi kepustakaan yaitu mengkaji bukubuku, jurnal, skripsi terdahulu dan lainlainnya yangmasih berkaitan dengan penelitian ini. Selain itu, data-data diperoleh dari instansi terkait yaitu bank syariah, Bank Indonesia serta Badan Pusat Statistika yang relevan dengan analisis dan pembahasan penelitian

\section{Tekhnik Analisis}

Tekhnik analisis yang digunakan dalam penelitian ini adalah regresi linear berganda dengan time series. Tekhnik analisis ini dipakai untuk memperoleh informasi ada atau tidak pengaruh dana pihak ketigga, tingkat inflasi, pendapatan perkaita dan imbalan SWBI terhadap jumlah dana talangan haji. Adapun alat analisis yang digunakan adalah SPSS versi 20.

Teknik analisis yang digunakan pada penelitian ini adalah teknik analisis regresi linier berganda (multiple regression analysis). Berdasarkan variabel yang digunakan maka hubungan antar variabel dalam penelitian ini dapat dinyatakan dalam fungsi sebagai berikut :

$$
Y=f\left(X_{1}, X_{2}, X_{3}, X_{4}\right)
$$

Bentuk persamaan regresi linier bergandanya dapat dirumuskan sebagai berikut:

$$
Y=\beta_{0}+\beta_{1} X_{1}+\beta_{2} X_{2}+\beta_{3} X_{3}+\beta_{4} X_{4}+e
$$

Keterangan :

$Y=$ Jumlah Besaran Pembiayaan Dana

Talangan Haji

$X_{1}=$ Dana Pihak Ketiga

$X_{2}=$ Tingkat Inflasi

$X_{3}=$ Pendapatan Perkapita

$X_{4}=\mid \mathrm{mbal}$ Bonus SWBI

$B_{0}=$ Konstanta

$\beta_{1}, \beta_{2}, \beta_{3}, \beta_{4} \quad=$ Koefisien Regresi Variabel $X$

$e=$ Variabel Error

\section{HASIL DAN PEMBAHASAN}

Dalam penelitian ini, analisis data pertama menunjukkan bahwa data penelitian belum lolos syarat uji asumsi klasik. Hal ini ditandai dengan adanya masalah autokorelasi dan multikolinearitas pada uji asumsi klasik. Salah satu metode yang digunakan untuk mendeteksi gejala autokorelasi adalah dengan melihat nilai Durbin-Watson. Jika nilai $\mathrm{dU}<\mathrm{DW}<4-\mathrm{dU}$ maka dapat dikatakan terbebas dari masalah autokorelasi Berikut adalah tabel hasil SPSS yang menunjukkan adanya masalah autokorelasi:

Tabel 2.

Uji Autokorelasi

\begin{tabular}{|l|l|l|l|}
\hline $\begin{array}{l}\text { Nilai } \\
\text { Durbin- } \\
\text { Watson }\end{array}$ & $\begin{array}{l}\text { Nilai du } \\
\text { dan d. }\end{array}$ & $\begin{array}{l}\text { Intepretasi } \\
\text { Hasil }\end{array}$ & Keterangan \\
\hline 0,232 & du: 1,74 & DW $<$ du & Terjadi \\
\hline
\end{tabular}


Setyawan, et al/Jurnal Ekonomi Syariah Teori dan Terapan Vol. 4 No. 3 Maret 2017: 235-252; DETERMINAN FAKTOR INTERNAL DANA PIHAK KETIGA DAN FAKTOR EKSTERNAL (INFLASI, PENDAPATAN PERKAPITA, DAN IMBALAN SWBI) TERHADAP JUMLAH DANA TALANGAN HAJI PADA BANK SYARIAH(BNI SYARIAH, BRI SYARIAH, BANK MUAMALAT, BANK SYARIAH MANDIRI)

PERIODE 2009-2014

\begin{tabular}{|l|l|l|l}
\hline $\mathrm{d}: 1,49$ & Autokorelasi \\
\hline
\end{tabular}

Sumber: hasil uji SPSS (data telah diolah).

Tabel di atas menunjukkan bahwa nilai Durbin-Watson sebesar 0,232 dan jika dibandingkan dengan $\mathrm{dU}$ dan $\mathrm{dL}$ tabel dengan $a=5 \%$ maka didapat $d U=1,74$ dan $\mathrm{dL}=1,49$, sehingga tidak memenuhi syarat bebas autokorelasi dan disimpulkan variabel dalam penelitian mengalami masalah autokorelasi

Selain mengalami masalah autokorelasi, data penelitian juga mengalami masalah multikolinearitas yang ditunjukkan dari hasil nilai VIF dan tolerance yang tidak memenuhi kriteria.Untuk mendeteksi gejala multikolinearitas dapat dilihat dari nilai variaance inflating factor (VIF) dan nilai dari tolerance (TOL). Jika nilai VIF lebih dari 10 dan nilai TOL semakin dekat 0 maka terdapat masalah multikolinearitas. Jika nilai VIF kurang dari 10 dan nilai TOL semakin dekat 1 maka tidak terdapat masalah multikolinearitas. Berikut adalah tabel hasil analisis SPSS yang menunjukkan adanya masalah multikolinearitas:

Tabel 3.

Uji Multikolinearitas

\begin{tabular}{|l|c|c|l|l|}
\hline $\begin{array}{l}\text { Variabel } \\
\text { Bebas }\end{array}$ & Nilai VIF & $\begin{array}{l}\text { Nilai } \\
\text { TOL }\end{array}$ & Intepretasi Hasil & Ket: \\
\hline $\begin{array}{l}\text { Dana } \\
\text { Pihak } \\
\text { Ketiga }\end{array}$ & 16,103 & $\begin{array}{c}0,06 \\
2\end{array}$ & $\begin{array}{l}\text { Nilai tolerance } \\
\text { mendekati 0 } \\
\text { Nilai VIF > 10 }\end{array}$ & $\begin{array}{l}\text { Terjadi } \\
\text { Multikoli } \\
\text { nearitas }\end{array}$ \\
\hline $\begin{array}{l}\text { Tingkat } \\
\text { Inflasi }\end{array}$ & 1,682 & $\begin{array}{c}0,59 \\
4\end{array}$ & $\begin{array}{l}\text { Nilai tolerance } \\
\text { menjauhi 0 } \\
\text { Nilai VIF }<10\end{array}$ & $\begin{array}{l}\text { Tidak } \\
\text { Terjadi } \\
\text { Multikoli } \\
\text { nearitas }\end{array}$ \\
\hline $\begin{array}{l}\text { Pendapa } \\
\text { tan } \\
\text { Perkapita }\end{array}$ & 19,814 & 0,05 & $\begin{array}{l}\text { Nilai tolerance } \\
\text { mendekati 0 } \\
\text { Nilai VIF }>10\end{array}$ & $\begin{array}{l}\text { Terjadi } \\
\text { Multikoli } \\
\text { nearitas }\end{array}$ \\
\hline $\begin{array}{l}\text { Imbalan } \\
\text { SWBI }\end{array}$ & 3,162 & 0,31 & $\begin{array}{l}\text { Nilai tolerance } \\
\text { menjauhi 0 } \\
\text { Nilai VIF < 10 }\end{array}$ & $\begin{array}{l}\text { Tidak } \\
\text { Terjadi } \\
\text { Multikoli } \\
\text { nearitas }\end{array}$ \\
\hline
\end{tabular}

Sumber: Lampiran 3, hasil uji SPSS (data telah diolah).

Tabel di atas menunjukkan bahwa terdapat dua variabel yang mengalami masalah multikolinearitas. Hal ini terlihat dari variabel dana pihak ketiga dan pendapatan perkapita yang memiliki nilai VIF lebih dari 10 dan nilai tolerance yang mendekati 0 . Dengan demikian dapat dikatakan bahwa pada hasil analisis pertama data mengalami masalah multikorelasi sehingga belum lolos syarat uji asumsi klasik. Pada penelitian ini hasil analisis data yang pertama menunjukkan adanya masalah autokorelasi dan multikolinearitas. Sehingga dilakukan penyembuhan dengan menggunakan metode first difference. Setelah dilakukan metode first difference ternyata setelah diolah kembali, hasil regresi mengalami masalah multikorelasi atau korelasi ganda. Adanya masalah multikorelasi ini ditunjukkan oleh hasil uji $F$ yang menunjukkan pengaruh signifikan tetapi pada uji $t$ setengah dari variabel bebas secara parsial tidak menunjukkan pengaruh yang signifikan. Mengenai persoalan ini, Gujarati (2009:331) menjelaskan bahwa "Indeed, this is one of the signals of multicollinearity - insignificant $t$ values but a high overall $R^{2}$ (and a significant $F$ value)". Hal yang sama juga disampaikan oleh Supranto (2004:25), yang menjelaskan bahwa "uji $F$ (= Ftest) hasilnya sangat signifikan dan uji t hasilnya tidak signifikan, ini berarti bahwa variabel mengalami masalah korelasi". Dari 
Setyawan, et al/Jurnal Ekonomi Syariah Teori dan Terapan Vol. 4 No. 3 Maret 2017: 235-252; DETERMINAN FAKTOR INTERNAL DANA PIHAK KETIGA DAN FAKTOR EKSTERNAL (INFLASI, PENDAPATAN PERKAPITA, DAN IMBALAN SWBI) TERHADAP JUMLAH DANA TALANGAN HAJI PADA BANK SYARIAH(BNI SYARIAH, BRI SYARIAH, BANK MUAMALAT, BANK SYARIAH MANDIRI)

PERIODE 2009-2014

penjelasan di atas, dapat diambil kesimpulan bahwa jika nilai uji $F$ signifikan, akan tetapi pada uji + terdapat separuh atau lebih variabel yang secara parsial tidak signifikan maka dapat dikatakan masih terdapat masalah multikorelasi dalam hasil regresi tersebut.

Untuk mengatasi masalah ini, maka variabel yang berkorelasi dikeluarkan dari model regresi. Hal itu dilakukan untuk menghindari hasil regresi yang bias. Pada penelitian ini hasil uji $t$ variabel dana pihak ketiga dan tingkat inflasi tidak menunjukkan pengaruh yang signifikan padahal pada uji $F$ menunjukkan pengaruh yang signifikan terhadap variabel terikatnya. Hal ini mengindikasikan bahwa variabel dana pihak ketiga dan tingkat inflasi mengalami masalah kolinearitas ganda sehingga harus dikeluarkan dari model regresi untuk menghindari penelitian yang bias.

\section{Uji Asumsi KlasiK}

\section{Uji Autokorelasi}

Uji autokorelasi digunakan untuk menguji adanya korelasi antara varian error atau pengganggu pada periode tertentu dengan periode sebelumnya. salah satu metode yang digunakan untuk mendeteksi gejala autokorelasi adalah dengan melihat nilai Durbin-Watson. Jika nilai $d_{u}<D W<4$ - du maka dapat dikatakan terbebas dari masalah autokorelasi. Berikut tabel yang menunjukkan hasil uji autokorelasi setelah dilakukan metode first difference:
Tabel 4.

Uji Autokorelasi Setelah Penyembuhan dengan Metode First Difference

\begin{tabular}{|l|l|l|l|}
\hline $\begin{array}{l}\text { Nilai } \\
\text { Durbin- } \\
\text { Watson }\end{array}$ & $\begin{array}{l}\text { Nilai du } \\
\text { dan d }\end{array}$ & $\begin{array}{l}\text { Intepretasi } \\
\text { Hasil }\end{array}$ & Ket: \\
\hline 1,829 & $\begin{array}{l}\text { du: 1,74 } \\
\text { d : 1,49 }\end{array}$ & $\begin{array}{l}\text { du<DW }< \\
4-d u\end{array}$ & $\begin{array}{l}\text { Tidak } \\
\text { terjadi } \\
\text { autokorel } \\
\text { asi }\end{array}$ \\
\hline
\end{tabular}

Sumber: hasil uji SPSS (data telah diolah).

Berdasarkan tabel di atas, nilai Durbin-Watson sebesar 1,829 yaitu lebih besar dari nilai dU tetapi lebih kecil dari nilai 4 - dU sehingga memenuhi syarat uji autokorelasi. Dengan demikian dapat dikatakan bahwa variabel yang ada dalam penelitian ini sudah terbebas dari masalah autokorelasi, sehingga variabel bebas dapat digunakan untuk menjelaskan variabel terikatnya.

\section{Uji Multikolinearitas}

Uji multikolinearitas bertujuan untuk mendeteksi adanya korelasi atau hubungan antar variabel independen dalam penelitian. Model regresi yang baik seharusnya tidak terjadi korelasi diantara variabel independen. Berikut tabel yang menunjukkan hasil pengujian multikolinearitas setelah dilakukan first difference:

Tabel 5.

Uji Multikolinearitas Setelah Dilakukan Metode First Difference

\begin{tabular}{|l|c|c|l|l|}
\hline $\begin{array}{l}\text { Variabel } \\
\text { Bebas }\end{array}$ & $\begin{array}{l}\text { Nilai } \\
\text { VIF }\end{array}$ & $\begin{array}{l}\text { Nilai } \\
\text { TOL }\end{array}$ & $\begin{array}{l}\text { Intepret } \\
\text { asi Hasil }\end{array}$ & Ket: \\
\hline $\begin{array}{l}\text { Pendap } \\
\text { atan } \\
\text { perkapit } \\
\text { a }\end{array}$ & 1,001 & 0,999 & $\begin{array}{l}\text { Nilai } \\
\text { toleranc } \\
\text { e>0 } \\
\text { Nilai VIF } \\
<10\end{array}$ & $\begin{array}{l}\text { Tidak } \\
\text { Terjadi } \\
\text { Multiko } \\
\text { linearit } \\
\text { as }\end{array}$ \\
\hline SWBI & 1,001 & 0,999 & $\begin{array}{l}\text { Nilai } \\
\text { toleranc } \\
\text { e>0 } \\
\text { Nilai VIF }\end{array}$ & $\begin{array}{l}\text { Tidak } \\
\text { Terjadi } \\
\text { Multiko } \\
\text { linearit }\end{array}$ \\
\hline
\end{tabular}


Setyawan, et al/Jurnal Ekonomi Syariah Teori dan Terapan Vol. 4 No. 3 Maret 2017: 235-252; DETERMINAN FAKTOR INTERNAL DANA PIHAK KETIGA DAN FAKTOR EKSTERNAL (INFLASI, PENDAPATAN PERKAPITA, DAN IMBALAN SWBI) TERHADAP JUMLAH DANA TALANGAN HAJI PADA BANK SYARIAH(BNI SYARIAH, BRI SYARIAH, BANK MUAMALAT, BANK SYARIAH MANDIRI)

Sumber: hasil uji SPSS (data telah diolah). Tabel di atas menjelaskan bahwa nilai tolerance dari masing-masing variabel nilainya lebih dari 0 dan nilai VIF kurang dari 10 sehingga dapat dikatakan bahwa variabel bebas dalam penelitian ini sudah terbebas dari masalah multikolinearitas. Dengan dipenuhinya syarat uji multikolinearitas maka variabel bebas dalam penelitian ini dapat digunakan untuk menjelaskan variabel terikatnya.

\section{Uji Heteroskedastisitas}

Uji heteroskedastisitas digunakan untuk menguji ada atau tidaknya hubungan antara variabel pengganggu dengan variabel bebasnya. Jika tidak terjadi masalah heteroskedastisitas maka tidak terjadi pula hubungan antara variabel pengganggu dengan variabel bebasnya sehingga variabel terikat benarbenar hanya dijelaskan oleh variabel bebasnya. Cara mendeteksi ada atau tidaknya gejala heteroskedastisitas adalah dengan melihat pola penyebaran pada grafik scattered plot. Jika titik-titik menyebar di atas dan di bawah angka 0 pada sumbu $Y$ dan tidak membentuk pola yang jelas maka tidak terjadi gejala heteroskedastisitas. Berikut hasil uji heteroskedastisitas menggunakan grafik scattered plot

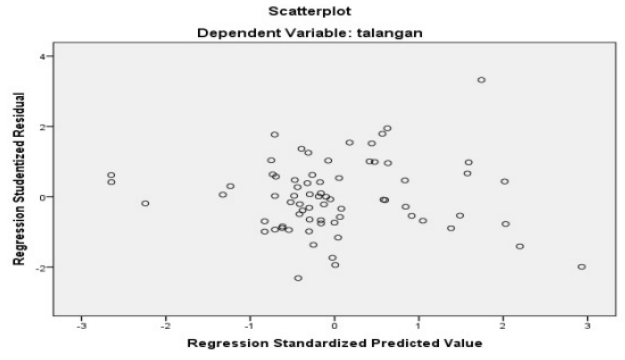

Sumber: Hasil Uji SPSS (data telah diolah). Gambar di atas menunjukkan pola titik-titik yang tersebar di sekitar angka 0 pada sumbu $Y$ dan tidak membentuk pola yang jelas. Titik-titik tersebut menyebar di atas dan di bawah angka 0 sehingga dapat disimpulkan bahwa di dalam model regresi ini tidak terjadi heteroskedastisitas

\section{Uji Normalitas}

Uji normalitas dilakukan untuk melihat masing-masing variabel berdistribusi normal atau tidak. Metode yang digunakan untuk melihat uji normalitas adalah grafik probability plot. Jika data menyebar di sekitar garis diagonal dan mengikuti arah garis diagonal maka variabel dalam penelitian telah terdistribusi secara normal dan model regresi telah memenuhi asumsi normalitas. Berikut adalah hasil uji normalitas menggunakan grafik probability plot:

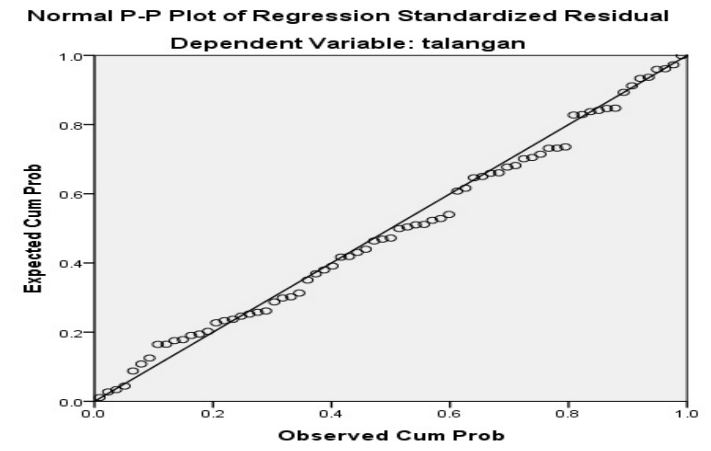

Sumber: Hasil Uji SPSS (data telah diolah). 
Setyawan, et al/Jurnal Ekonomi Syariah Teori dan Terapan Vol. 4 No. 3 Maret 2017: 235-252; DETERMINAN FAKTOR INTERNAL DANA PIHAK KETIGA DAN FAKTOR EKSTERNAL (INFLASI, PENDAPATAN PERKAPITA, DAN IMBALAN SWBI) TERHADAP JUMLAH DANA TALANGAN HAJI PADA BANK SYARIAH(BNI SYARIAH, BRI SYARIAH, BANK MUAMALAT, BANK SYARIAH MANDIRI)

PERIODE 2009-2014

Gambar di atas menunjukkan bahwa data menyebar di sekitar garis diagonal dan mengikuti arah garis diagonal. Dengan demikian dapat disimpulkan bahwa data telah terdistribusi secara normal dan model regresi telah memenuhi asumsi normalitas

\section{Analisis Regresi Linear Berganda}

Analisis regresi linear berganda merupakan model analisis untuk mengetahui pengaruh variabel bebas terhadap variabel terikatnya. Selanjutnya, dari hasil analisis regresi linear berganda akan diperoleh persamaan yang menunjukkan model regresi dari penelitian ini. Pada penelitian ini variabel dana pihak ketiga dan tingkat inflasi terindikasi mengalami masalah kolinearitas ganda sehingga harus dikeluarkan dari model regresi untuk menghindari penelitian yang bias. Berikut persamaan regresi linear berganda yang diperoleh dari hasil olahan menggunakan SPSS setelah dilakukan first difference dan variabel dana pihak ketiga dan tingkat inflasi dikeluarkan dari model regresi:

Tabel 6

Analisis Regresi Linear Berganda

\begin{tabular}{|l|l|l|}
\hline Variabel & Koefisien B & Keterangan \\
\hline Konstanta & $-347503184,3$ & Konstata \\
\hline $\begin{array}{l}\text { Pendapatan } \\
\text { perkapita }\end{array}$ & 26029,094 & Bernilai positif \\
\hline Imbalan SWBI & -3620634256 & Bernilai negatif \\
\hline
\end{tabular}
diolah).

Tabel di atas menunjukkan hasil regresi linear berganda dengan variabel pendapatan perkapita dan imbalan SWBI sebagai variabel bebas dan dana talangan haji sebagai variabel terikat.
Terlihat bahwa pendapatan perkapita bernilai positif artinya memiliki hubungan yang searah dengan dana talangan haji. Imbalan SWBI bernilai negatif artinya bahwa memiliki hubungan yang tidak searah dengan dana talangan haji,

Tabel 6 menujukkan persamaan regresi linear bergandasebagai berikut:

$Y=-347503184,3+26029,094$ (pendapatan) - 3620634256(SWBI).

a. Konstata sebesar $-347503184,3$ menunjukkan apabila variabel imbalan SWBI dan pendapatan perkapita besarnya nol atau konstan, maka nilai dana talangan haji sebesar 347.503.184,3 satuan rupiah.

b. Koefisien regresi pendapatan perkapita $\left(X_{1}\right)$ sebesar 26029,094 atau $\frac{\delta y}{\delta x}=$. 26029,094. Koefisien bernilai positif artinya setiap kenaikan sebesar satu satuan rupiah dari pendapatan perkapita akan meningkatkan jumlah dana talangan haji sebesar 26.029,094 satuan rupiah. Sebaliknya, setiap penurunan sebesar satu satuan rupiah dari pendapatan perkapita maka akan menyebabkan penurunan jumlah dana talangan haji sebesar 26.029,094 satuan rupiah dengan asumsi variabel yang lain adalah konstan.

Koefisien regresi imbalan SWBI sebesar $3620634256 a t a u \frac{\delta y}{\delta x}=-3620634256$. Koefisien bernilai negatif artinya setiap kenaikan sebesar satu persen dari imbalan SWBI akan menyebabkan penurunan jumlah dana talangan haji 
Setyawan, et al/Jurnal Ekonomi Syariah Teori dan Terapan Vol. 4 No. 3 Maret 2017: 235-252; DETERMINAN FAKTOR INTERNAL DANA PIHAK KETIGA DAN FAKTOR EKSTERNAL (INFLASI, PENDAPATAN PERKAPITA, DAN IMBALAN SWBI) TERHADAP JUMLAH DANA TALANGAN HAJI PADA BANK SYARIAH(BNI SYARIAH, BRI SYARIAH, BANK MUAMALAT, BANK SYARIAH MANDIRI)

PERIODE 2009-2014

sebesar 3.620.634.256 satuan rupiah. Sebaliknya, setiap penurunan sebesar satu satuan rupiah dari pendapatan perkapita maka akan menyebabkan penurunan jumlah dana talangan haji sebesar 3.620.634.256 satuan rupiah dengan asumsi variabel yang lain adalah konstan.

\section{Analisis Koefisien Determinasi Berganda}

Analisis koefisien determinasi

dilakukan untuk mengukur seberapa jauh kemampuan variabel bebas dalam menjelaskan variabel terikatnnya. Nilai koefisien determinasi adalah diantara 0 dan 1. Nilai yang mendekati 1 maka variabel-variabel bebas memberikan hampir semua informasi yang dibutuhkan untuk memprediksi variasi variabel terikat. Berikut adalah hasil dari koefisien determinasi berganda:

Tabel 7.

Hasil Koefisien Determinasi Berganda

\begin{tabular}{l} 
Model Summary \\
\begin{tabular}{|l|c|r|l|l|c|}
\hline Model & \multicolumn{1}{c|}{$R$} & R Square & $\begin{array}{l}\text { Adjusted R } \\
\text { Square }\end{array}$ & $\begin{array}{l}\text { Std. Error of } \\
\text { the Estimate }\end{array}$ & $\begin{array}{c}\text { Durbin- } \\
\text { Watson }\end{array}$ \\
\hline 1 & $.567^{\mathrm{a}}$ & .322 & .302 & 21536315725 & 1.829 \\
\hline
\end{tabular} \\
\hline
\end{tabular}

Sumber: Hasil uji SPSS (data telah diolah). Tabel 7 menunjukkan nilai Rsquare yaitu sebesar 0,322 atau sebesar 32,2\%, artinya bahwa variabel bebas yaitu imbalan Sertifikat Wadiah Bank Indonesia dan pendapatan perkapita dapat menjelaskan variabel terikat yaitu dana talangan haji sebesar 32,2\%. Dan sisanya yaitu $67,8 \%$ dijelaskan oleh variabel- variabel lain di luar variabel bebas yang digunakan dalam penelitian ini.

\section{Pengujian Hipotesis}

Uji $F$

Berikut hasil dari analisis nilai $F$ hitung dan Ftabel serta nilai sig. hasil pengolahan SPSS setelah dilakukan first difference:

Tabel 8.

Hasil Uji Hipotesis (Uji F)

\begin{tabular}{|l|l|l|l|}
\hline $\mathrm{F}_{\text {hitung }}$ & $\mathrm{F}_{\text {tabel }}$ & Intepretasi & Ket: \\
\hline 16,111 & 2,346 & $\mathrm{~F}_{\text {hitung }}>\mathrm{F}$ & Ho ditolak \\
& & tabel & sehingga \\
& & $16,111>$ & variabel \\
& & 2,346 & bebas \\
& $=$ Ho ditolak & secara \\
& & simultan \\
& & berpengaruh \\
& & signifikan \\
& & terhadap \\
& & variabel \\
& & & dependen. \\
\hline
\end{tabular}

Sumber: hasil analisis SPSS (data telah diolah).

Tabel 8 menunjukkan hasil uji $F$ dengan kesimpulan bahwa $\mathrm{H}_{0}$ ditolak karena nilai Fhitung lebih besar dibandingkan $F_{\text {tabel }}$ nya dan nilai sig. lebih kecil dari 0,05 sehingga menjelaskan variabel bebas (imbalan SWBI dan pendapatan perkapita) secara simultan berpengaruh signifikan terhadap variabel terikat jumlah besaran dana talangan haji.

Uji $t$

Berikut hasil uji $t$ statistik hasil pengolahan SPSS setelah dilakukan first difference:

Tabel 9.

Hasil Uji Hipotesis (Uji $t$ )

\begin{tabular}{|c|c|c|c|c|}
\hline $\begin{array}{l}\text { Variabel } \\
\text { bebas }\end{array}$ & $t_{\text {hitung }}$ & $t_{\text {tabel }}$ & $\begin{array}{l}\text { Intepret } \\
\text { asi }\end{array}$ & Ket: \\
\hline Imbalan SWBI & $-3,638$ & 1,997 & $\begin{array}{l}\text { Sig. }< \\
0,05 \\
t_{\text {hitung }}>t_{\text {ta }} \\
\text { bel }\end{array}$ & $\begin{array}{l}\text { Signifi } \\
\text { kan }\end{array}$ \\
\hline
\end{tabular}


Setyawan, et al/Jurnal Ekonomi Syariah Teori dan Terapan Vol. 4 No. 3 Maret 2017: 235-252; DETERMINAN FAKTOR INTERNAL DANA PIHAK KETIGA DAN FAKTOR EKSTERNAL (INFLASI, PENDAPATAN PERKAPITA, DAN IMBALAN SWBI) TERHADAP JUMLAH DANA TALANGAN HAJI PADA BANK SYARIAH(BNI SYARIAH, BRI SYARIAH, BANK MUAMALAT, BANK SYARIAH MANDIRI)

PERIODE 2009-2014

\begin{tabular}{|l|l|l|l|l|}
\hline $\begin{array}{l}\text { Pendapatan } \\
\text { perkapita }\end{array}$ & 4,222 & 1,997 & $\begin{array}{l}\text { Sig. }< \\
0,05 \\
\text { thitung }>t_{\text {ta }} \\
\text { bel }\end{array}$ & $\begin{array}{l}\text { Signifi } \\
\text { kan }\end{array}$ \\
\hline
\end{tabular}

Sumber: hasil analisis SPSS (data telah diolah).

Berdasarkan tabel 9 dapat
dijelaskan pengujian hipotesis untuk
pengaruh setiap variabel bebas terhadap
variabel terikat adalah sebagai berikut:

a. Variabel imbalan SWBI memiliki thitung sebesar 3,638 dengan tabel sebesar 1,997 maka thitung lebih besar dari tabel sehingga $\mathrm{H}_{0}$ diterima. Nilai sig. sebesar 0,001 lebih kecil dari 0,05 sehingga disimpulkan bahwa imbalan SWBI berpengaruh signifikan secara parsial terhadap jumlah dana talangan haji.

b. Variabel pendapatan perkapita memiliki thitung sebesar 4,222 dengan $t_{\text {tabel }}$ sebesar 1,997 maka thitung lebih besar dari tabel sehingga $\mathrm{H}_{0}$ diterima. Nilai sig. sebesar 0,000 yang lebih kecil dari 0,05 sehingga disimpulkan bahwa pendapatan perkapita berpengaruh signifikan secara parsial terhadap jumlah dana talangan haji.

\section{Pembahasan}

Berdasarkan hasil pengolahan data dapat dianalisa bahwa model regresi yang pertama mengalami masalah autokorelasi yang ditunjukkan dari nilai uji Durbin-Watson sebesar 0,206 yang masih berada di bawah nilai du tabel. Pada penelitian ini metode yang digunakan untuk menyembuhkan masalah autokorelasi tersebut adalah metode first difference. Metode first difference dilakukan dengan cara mengurangkan setiap variabel periode $t$ dengan periode sebelumnya $t-1$. Dampak dari metode tersebut adalah jumlah sampel data berkurang satu dari jumlah sampel data semula sehingga menghasilkan tabulasi baru untuk pemrosesan data menggunakan SPSS. Pada penelitian ini hasil pengujian yang dipakai untuk kemudian dianalisa adalah hasil setelah dilakukannya metode first difference. Selain itu, dalam penelitian ini variabel jumlah dana pihak ketiga dan tingkat inflasi terindikasi mengalami masalah kolinearitas ganda sehingga kedua variabel tersebut dikeluarkan dari model regresi untuk menghindari hasil regresi yang bias.

\section{Pengaruh Imbalan SWBI Secara Parsial}

\section{Terhadap Jumlah Dana Talangan Haji}

Pengaruh Imbalan SWBI secara parsial terhadap jumlah dana talangan haji dapat diketahui dari hasil uji t. Dari hasil pengolahan didapat bahwa imbalan SWBI memiliki pengaruh signifikan terhadap jumlah dana talangan haji pada empat bank syariah (Bank Syariah Mandiri, BNI Syariah, Bank Muamalat dan BNI Syariah) selama periode Januari 2009 hingga Desember 2014. Hasil analisa tersebut dibuktikan dari nilai thitung sebesar 3,638 dan trabel sebesar 1,997 sehingga thitung ttabel. $_{\text {t }}$ Hal ini juga dikuatkan oleh nilai sig. sebesar $0,001<0,05$ sehingga disimpulkan menerima $\mathrm{H}_{0}$ atau menolak $H_{1}$. Nilai thitung dari hasil pengujian untuk variabel imbalan SWBI bernilai negatif (3,638 ) yang menunjukkan adanya 
Setyawan, et al/Jurnal Ekonomi Syariah Teori dan Terapan Vol. 4 No. 3 Maret 2017: 235-252; DETERMINAN FAKTOR INTERNAL DANA PIHAK KETIGA DAN FAKTOR EKSTERNAL (INFLASI, PENDAPATAN PERKAPITA, DAN IMBALAN SWBI) TERHADAP JUMLAH DANA TALANGAN HAJI PADA BANK SYARIAH(BNI SYARIAH, BRI SYARIAH, BANK MUAMALAT, BANK SYARIAH MANDIRI)

PERIODE 2009-2014

hubungan tidak searah antara imbalan SWBI dengan jumlah dana talangan haji. Artinya setiap peningkatan dari imbalan SWBI akan diikuti oleh penurunan jumlah dana talangan haji, begitu juga sebaliknya.

Penempatan dana oleh lembaga bank di Bank Indonesia, berkaitan sekali dengan kebijakan yang akan diambil oleh lembaga bank tersebut. Semakin tinggi lembaga bank menempatkan dananya pada Bank Indonesia maka akan semakin rendah kemampuan penyaluran pembiayaan oleh bank syariah tersebut. Sebaliknya, semakin rendah penempatan dana di Bank Indonesia maka semakin tinggi tingkat penyaluran dana untuk pembiayaan pada lembaga bank syariah. Imbalan SWBI yang tinggi akan menarik minat bank syariah untuk menempatkan dananya pada instrument SWBI daripada disalurkan pada produk seperti dana talangan haji. Bank syariah tentu akan memilih menempatkan dananya pada investasi yang memberikan keuntungan yang lebih besar. Dengan semakin tingginya penempatan dana pada instrument SWBI maka berdampak pada semakin menurunnya dana yang disalurkan untuk dana talangan haji yang pada akhirnya menyebabkan turunnya jumlah dana talangan haji di bank syariah.

Dalam pandangan Islam, SWBI diperbolehkan karena tidak mengandung riba dalam pemberian imbalan kepada pemegang sertifikat tersebut. Pemberian imbalan yang nilainya tidak pasti pada SWBI hanya sebagai bonus. Artinya bahwa nilai imbalan yang diberikan pada SWBI tidak didasarkan pada nilai pokok sertifikat tersebut. Pada dasarnya, Islam hanya melarang sesuatu yang mengandung riba, sedangkan untuk bonus diperbolehkan karena merupakan bentuk sukarela dari pihak yang memberikan bonus. Larangan riba telah dijelaskan di dalam Al-Qur'an surat Ali Imron ayat 130:

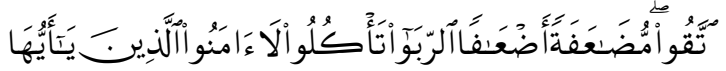

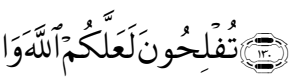

Yang artinya: "Hai orang-orang yang beriman, janganlah kamu memakan Riba dengan berlipat ganda dan bertakwalah kamu kepada Allah supaya kamu mendapat keberuntungan".

Dalil di atas menjelaskan bahwa, Allah SWT dan Rasul-Nya melarang adanya riba. Akan tetapi Allah SWT memperbolehkan jual beli melalui perniagaan. Allah SWT juga tidak melarang adanya pemberian bonus, sebab bonus hanya bersifat sukarela dan nilainya tidak pasti. Berbeda dengan riba yang nilainya telah pasti ditetapkan di awal transaksi.

\section{Pengaruh Pendapatan Perkapita Secara} Parsial Terhadap Jumlah Dana Talangan Haji

Pengaruh pendapatan perkapita secara parsial terhadap jumlah dana talangan haji dapat diketahui dari hasil uji t. Dari hasil pengolahan didapat bahwa pendapatan perkapita memiliki pengaruh signifikan terhadap jumlah dana talangan 
Setyawan, et al/Jurnal Ekonomi Syariah Teori dan Terapan Vol. 4 No. 3 Maret 2017: 235-252; DETERMINAN FAKTOR INTERNAL DANA PIHAK KETIGA DAN FAKTOR EKSTERNAL (INFLASI, PENDAPATAN PERKAPITA, DAN IMBALAN SWBI) TERHADAP JUMLAH DANA TALANGAN HAJI PADA BANK SYARIAH(BNI SYARIAH, BRI SYARIAH, BANK MUAMALAT, BANK SYARIAH MANDIRI)

PERIODE 2009-2014

haji pada empat bank syariah (Bank Syariah Mandiri, BRI Syariah, Bank M vamalat dan BNI Syariah) selama periode Januari 2009 hingga Desember 2014. Hasil analisa tersebut dibuktikan dari nilai thitung sebesar 4,222 dan tabel sebesar 1,997 sehingga $t_{\text {hitung }}>$ ttabel. $_{\text {t }}$ Hal ini juga dikuatkan oleh nilai sig. sebesar $0,000<0,05$ sehingga disimpulkan menerima $\mathrm{H}_{0}$ atau menolak $H_{1}$. Nilai $\dagger$ hitung dari hasil pengujian untuk variabel pendapatan perkapita bernilai positif $(4,222)$ yang menunjukkan adanya hubungan searah antara pendapatan perkapita dengan jumlah dana talangan haji. Artinya bahwa setiap peningkatan dana pihak ketiga akan disertai pula oleh kenaikan jumlah dana talangan haji, begitu juga sebaliknya.

Dalam suatu negara, semakin tinggi tingkat pendapatan perkapita masyarakat semakin tinggi pula tingkat kesejateraan ekonomi masyarakat tersebut. Jika kesejahteraan ekonomi masyarakat meningkat maka kebutuhan hidup masyarakat, baik kebutuhan rohani maupun jasmani akan dapat semakin terpenuhi. Sebaliknya, semakin rendah tingkat pendapatan perkapita masyarakat, maka semakin rendah pula tingkat kesejahteraan ekonomi masyarakat tersebut. Pendapatan merupakan salah satu faktor yang dapat mempengaruhi minat masyarakat untuk mendaftarkan diri untuk keberangkatan haji. Dalam suatu negara, semakin meningkat pendapatan perkapita masyarakat, semakin meningkat pula kesejateraan ekonomi masyarakat tersebut. Jika kesejahteraan ekonomi masyarakat meningkat maka kebutuhan hidup masyarakat, baik kebutuhan rohani maupun jasmani akan semakin lebih terpenuhi. Sebaliknya, semakin menurun pendapatan perkapita masyarakat, maka semakin menurun pula kesejahteraan ekonomi masyarakat tersebut. Salah satu kebutuhan rohani tersebut yaitu menunaikan ibdah haji. Jika pendapatan masyarakat meningkat, maka minat masyarakat untuk melaksanakan ibadah haji juga akan semakin meningkat. Minat masyarakat yang semakin tinggi untuk melaksanakan ibadah haji akan menyebabkan produk seperti dana talangan haji akan semakin diminati oleh masyarakat dan pada akhirnya akan meningkatkan jumlah dana talangan haji di bank syariah. Sehingga pendapatan perkapita mempunyai pengaruh besar untuk masyarakat dalam kebutuhan mereka dalam melaksanakan ibadah haji. Pendapatan perkapita sering digunakan sebagai tolok ukur kesejateraan ekonomi masyarakat suatu negara. Dalam pandangan Islam, seseorang yang mempunyai pendapatan yang cukup diwajibkan untuk menggunakan hartanya tersebut demi kebaikan di jalan Allah SWT. Hal ini adalah bentuk ketaqwaan seorang hamba kepada Tuhannya yang telah memberikan rezeki yang cukup. Jika seseorang diberikan pendapatan yang lebih maka hendaklah dia bersyukur atas 
Setyawan, et al/Jurnal Ekonomi Syariah Teori dan Terapan Vol. 4 No. 3 Maret 2017: 235-252; DETERMINAN FAKTOR INTERNAL DANA PIHAK KETIGA DAN FAKTOR EKSTERNAL (INFLASI, PENDAPATAN PERKAPITA, DAN IMBALAN SWBI) TERHADAP JUMLAH DANA TALANGAN HAJI PADA BANK SYARIAH(BNI SYARIAH, BRI SYARIAH, BANK MUAMALAT, BANK SYARIAH MANDIRI)

PERIODE 2009-2014

pendapatan yang diterimanya dengan cara memanfaatkan harta untuk kebaikan di jalan Allah SWT. Al-Qur'an menjelaskan dalam surat Al Baqarah ayat 265:

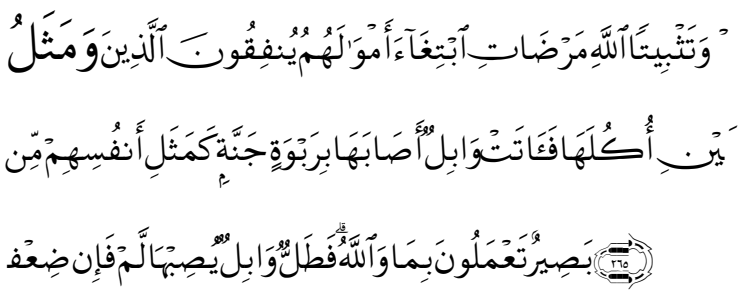

Yang artinya: "dan perumpamaan orangorang yang membelanjakan hartanya karena mencari keridhaan Allah dan untuk keteguhan jiwa mereka, seperti sebuah kebun yang terletak di dataran Tinggi yang disiram oleh hujan lebat, Maka kebun itu menghasilkan buahnya dua kali lipat. jika hujan lebat tidak menyiraminya, Maka hujan gerimis (pun memadai). dan Allah Maha melihat apa yang kamu perbuat".

Dalil di atas menjelaskan bahwa seseorang yang mempunyai pendapatan atau rezeki yang cukup, hendaklah dia bertaqwa dan bersyukur kepada Allah SWT yang telah memberikan rezeki tersebut. Salah satu bentuk ketaqwaan dan rasa syukur atas pendapatan yang cukup tersebut yaitu dengan cara digunakan untuk kebaikan di jalan Allah SWT salah satunya adalah menunaikan ibadah haji.

\section{SIMPULAN}

1. Pada penelitian ini sebagian hipotesis tidak terbukti. Hanya variabel pendapatan perkapita dan imbalan SWBI yang memenuhi hipotesis penelitian.

2. Imbalan SWBI secara parsial berpengaruh signifikan terhadap jumlah dana talangan haji pada bank syariah selama periode Januari 2009 hingga Desember 2014. Hubungan yang ditunjukkan adalah hubungan negatif yang berarti setiap kenaikan dari imbalan SWBI maka akan berdampak pada turunnya jumlah dana talangan haji pada bank syariah.

3. Pendapatan perkapita secara parsial berpengaruh signifikan terhadap jumlah dana talangan haji pada bank syariah selama periode Januari 2009 hingga Desember 2014. Hubungan yang ditunjukkan adalah hubungan positif yang berarti setiap kenaikan pendapatan perkapita, juga akan diikuti oleh kenaikan jumlah dana talangan haji pada bank syariah.

4. Imbalan SWBI dan perndapatan perkapita secara simultan berpengaruh signifikan terhadap jumlah dana talangan haji pada bank syariah selama periode Januari 2009 hingga Desember 2014. Hasil koefisien determinasi berganda sebesar 0,322 menunjukkan bahwa sebesar 32,2\% variabel terikat pada penelitian ini dapat dijelaskan oleh variabel bebasnya. Sedangkan sebesar $67,8 \%$ lainnya dijelaskan oleh variabel lain diluar variabel bebas yang digunakan dalam penelitian ini.

\section{DAFTAR PUSTAKA}


Anshori, Muslich dan Iswati. 2009. Metodologi Penelitian Kuantitatif. Surabaya: Airlangga University Press.

Arsyad, Lincolin. 2004. Ekonomi Pembangunan. Yogyakarta: STIE YKPN.

Ascarya dan Yumanita. 2004. Bank Syariah: Gambaran Umum. Jakarta: PT Raja Grafindo Persada.

Departemen Agama Republik Indonesia. 2006. Al-Quran dan Terjemahannya. Jakarta: CV Pustaka Agung Harapan.

Dendawijaya, Lukman. 2005. Manajemen Perbankan, Edisi Kedua, Cetakan Kedua. Bogor: Ghalia Indonesia.

Gujarati, Damodar. $2009 . \quad$ Basic Econometric:thirdedition, international edition. Singapore: McGraw-Hill, Inc.

Hasan, Iqbal. 2004. Analisis Data Penelitian dengan Statistik. Jakarta: PT. Bumi Aksara.

Khalwaty, Tajul, 2000. Inflasi dan Solusinya. Jakarta: Gramedia Pustaka Utama.

Komisi Fatwa MUI. 2002. Fatwa Dewan Syariah Nasional-Majelis Ulama Indonesia No. 29/DSN-MUI/VI/2002 tentang Dana Talangan Haji dan Jasa Pengurusan Haji. Jakarta: Majelis Ulama Indonesia.

Okumus, H.S. 2005. Joernal: A Studi of Customer Satisfaction and Bank Selection Criteria. Journal of Economic Cooperation.

Rivai, Veithzal dan Arviyal Arifin. 2008. Islamic Banking Sebuah Teori, Konsep, dan Aplikasi. Jakarta: Bumi Aksara.

Rosyidi, Suherman. 2003. Pengantar Teori Ekonomi Pendekatan kepada Ekonomi Mikro dan Makro. Jakarta: PT. Raja Grafindo Persada.

Supranto, J. 2004. Ekonometri:Buku Kedua. Jakarta: Ghalia Indonesia.

Widarjono, Agus. 2005. Ekonmetrika: Teori dan Aplikasi untuk Ekonomi dan Bisnis. Yogyakarta: Ekonosia 